\title{
Effect of fluoride solutions on color and surface roughness of dental composites
}

Efeito de soluções fluoretadas sobre a cor e rugosidade de superfície de compósitos odontológicos

\author{
Fabrício Mariano Mundim* \\ Diogo Rodrigues Cruvinel** \\ Lucas da Fonseca Roberti Garcia** \\ Fernanda de Carvalho Panzeri Pires-de-Souza ${ }^{* * * *}$
}

\begin{abstract}
Objective: The aim of this study was to assess the action of fluoride solutions on color stability $(\Delta E)$ and surface roughness $\left(R_{\mathrm{a}}\right.$ ) of composites (Heliomolar ${ }^{T M}, 4$ Seasons $^{T M}$, Tetric $\mathrm{N}^{-C^{2}}$ ram $^{T M}, S R$ Adoro $\left.^{T M}\right)$. Materials and method: A Teflon matrix $(12 \times 2 \mathrm{~mm})$ was used to fabricate 24 test specimens for each composite. The samples were separated into 4 groups $(n=6)$, according to the immersion solution: distilled water (control), acidulated phosphate fluoride (1.23\%), neutral sodium fluoride gel (2\%), and solution of sodium fluoride (0.05\%). Color (Spectrophotometer PCB 6807) and roughness (Surfcorder SE 1700) readings were performed before and after immersion into the solutions. Results: Composites presented color alteration within clinically acceptable limits $(\Delta E<3.3)$, increasing according to the periods of immersion. Regarding roughness, it was observed that $R_{a}$ values were lower than the critical limit to promote increase in dental biofilm retention $\left(R_{a}>0.2 \mu \mathrm{m}\right)$. Conclusions: Color and surface roughness alteration of the different composites was clinically acceptable after immersion in all fluoride solutions and in all periods.
\end{abstract}

Keywords: Composite resins. Color. Surface properties. Acidulated phosphate fluoride.

\section{Introduction}

Indirect composites were introduced in Dentistry to reduce the consequences of polymerization shrinkage and improve resistance to wear ${ }^{1-3}$. Studies observed that indirect composites present better mechanical properties and esthetic performance than direct composites; however, the color stability of these materials must be assessed after a long period of use .

Topical application of fluoride (TAF) has been used as an agent for preventing caries, and its effectiveness is widely recognized and studied ${ }^{5}$. Several types of fluoride solutions may be used for topical application, such as, $1.23 \%$ or $2 \%$ gels, $0.05 \%$ solutions for daily mouthrinsing, and varnishes indicated for intensive therapy ${ }^{6}$. Patients susceptible to dental caries should receive TAF for prevention ${ }^{6}$, and according to recommendations, $1.23 \%$ acidulated phosphate fluoride gel and $2 \%$ neutral fluoride gel should be applied on teeth for two minutes every 6 months $^{7,8}$.

DDS, MSc, PhD, Department of Dental Materials and Prosthodontics, Ribeirão Preto School of Dentistry, University of São Paulo, Ribeirão Preto, SP, Brazil.

DDS, MŚc, PhD, Department of Dental Materials and Prosthodontics, Ribeirão Preto School of Dentistry, University of São Paulo, Ribeirão Preto, SP, Brazil.

*** DDS, MSc, PhD, Department of Dental Materials and Prosthodontics, Ribeirão Preto School of Dentistry, University of São Paulo, Ribeirão Preto, SP, Brazil.

**** DDS, MŚc, PhD, Department of Dental Materials and Prosthodontics, Ribeirão Preto School of Dentistry, University of São Paulo, Ribeirão Preto, SP, Brazil. 
However, in vitro studies affirm that restorative materials surface, such as dental ceramics and dental composites, may be altered by the use of $\mathrm{TAF}^{9}$, which interferes in their microhardness and surface roughness, increasing porosity and allowing dyes and acids penetration, dental plaque accumulation, and hydrolysis of the polymeric matrix ${ }^{10}$. The fluoride ions of sodium fluoride present in topical fluoride solutions, and the hydrofluoric acid frequently present in acidulated phosphate fluoride may dissolve the surface layer of dental composites, promoting surface roughness increase and consequently, color stability reduction ${ }^{9,10}$.

Therefore, the aim of this study was to evaluate the action of different fluoride solutions, applied as clinical recommendations, on color stability and surface roughness of dental composites for periods that mimics from 1 to 5 years. The tested hypothe- ses were as follows: 1) acidulated fluoride solutions make the surface of restorative material rougher, interfering in light reflection and promoting color alteration; 2) neutral fluoride solutions or gel do not alter the surface or color of composites; and 3) when color and surface alterations occur, they are directly proportional to the time of action of the solutions.

\section{Materials and method}

To conduct this study, 4 dental composites in shade A2 were used, as shown in Table 1. Twenty-four test specimens of each dental composite were fabricated in a teflon matrix (12 $\mathrm{mm}$ in diameter $\mathrm{X}$ $2 \mathrm{~mm}$ thick) for color stability and surface roughness analysis.

Table 1 - Specifications of the studied composites

\begin{tabular}{|c|c|c|c|c|}
\hline Composite & Classification & Polymerization system & Composition ( $\%$ by volume) & Manufacturer \\
\hline Heliomolar ${ }^{\mathrm{TM}}$ & $\begin{array}{l}\text { Direct composite } \\
\text { with microparticles }\end{array}$ & $\begin{array}{l}\text { LED (FlashLite } 1401 \text {, Discus } \\
\text { Dental, Culver City, CA, USA - } \\
\text { light intensity } \geq 1100 \mathrm{~mW} / \mathrm{cm}^{2} \text {, } \\
\text { wavelength range of } 460 \text { and } 480 \\
\mathrm{~nm} \text { ). } \\
20 \text { seconds }\end{array}$ & $\begin{array}{l}\text { Bis-GMA (14.3\%); UDMA ( } 4.4 \%) \text {; DM- } \\
\text { DMA (3.3\%); } \mathrm{SiO}_{2} \text { highly dispersed } \\
(20.2 \%) ; \text { Copolymers }(47 \%) ; \mathrm{YbF}_{3^{\prime}} \\
(10.6 \%) ; \text { Stabilizers, catalyzers, and } \\
\text { pigments }(0.2 \%) \text {. } \\
\text { Size of fillers: } 0.04 \text { to } 0.2 \mu \mathrm{m} \\
\text { Percentage of inorganic fillers - } 64 \%\end{array}$ & $\begin{array}{l}\text { Ivoclar Vivadent } \\
\text { AG, Schaan, } \\
\text { Liechtenstein }\end{array}$ \\
\hline 4 Seasons $^{T M}$ & $\begin{array}{l}\text { Direct hybrid } \\
\text { composite with fine } \\
\text { particles }\end{array}$ & $\begin{array}{l}\text { LED (FlashLite 1401) } \\
20 \text { seconds }\end{array}$ & $\begin{array}{l}\text { Bis-GMA ( } 14.3 \%) \text {; UDMA ( } 4.4 \%) \text {; } \\
\text { Decanediol dimethacrylate }(3.3 \%) \text {; highly } \\
\text { dispersed silicone dioxide }(20.2 \%) ; \\
\text { Copolymers }(47 \%) \text {; Ytterbium trifluoride, } \\
(10.6 \%) ; \text { Stabilizers, catalyzers, and } \\
\text { pigments }(0.2 \%) \\
\text { Size of fillers: } 0.04-3.0 \mu \mathrm{mm} \\
\text { Percentage of inorganic fillers - } 55-58 \%\end{array}$ & Ivoclar Vivadent \\
\hline $\begin{array}{l}\text { Tetric } \\
\mathrm{N} \text {-Ceram }{ }^{\mathrm{TM}}\end{array}$ & $\begin{array}{l}\text { Nanohybrid direct } \\
\text { composite }\end{array}$ & $\begin{array}{l}\text { LED (FlashLite 1401) } \\
20 \text { seconds }\end{array}$ & $\begin{array}{l}\text { Bis-GMA (15\%), Bis-EMA ( } 3.8 \% \text { ) and } \\
\text { UDMA; Silanized barium glass ( }(30-40 \%) \text {; } \\
\text { Ytterbium trifluoride (1-5\%); Mixed } \\
\text { spheroid oxides (5-10\%); Copolymers (30- } \\
40 \%) ; \text { Stabilizers, catalyzers, and pigments. } \\
\text { Size of fillers: } 40-3.000 \mu \mathrm{m} \\
\text { Percentage of inorganic fillers - } 55-57 \%\end{array}$ & Ivoclar Vivadent \\
\hline SR Adoro' ${ }^{T M}$ & Indirect Composite & $\begin{array}{l}\text { Targis Power Upgrade (Ivoclar/ } \\
\text { Vivadent AG, Schaan, } \\
\text { Liechtenstein), at a temperature of } \\
104^{\circ} \mathrm{C} \text { for } 11 \text { minutes under light } \\
\text { and heat polymerization. }\end{array}$ & $\begin{array}{l}\text { Bis-GMA (20-42\%); TEGDMA (6-10\%); } \\
\text { UDMA (1-20\%); DM-DMA (0-7\%); } \mathrm{SiO}_{2} \\
\text { highly dispersed (19.8\%); Copolymers } \\
(62.9 \%) ; \text { Stabilizers and catalyzers }(0.4 \%) ; \\
\text { pigments }(0.1-0.3 \%) \text {. } \\
\text { Size of fillers: } 1 \text { and } 10 \mu \mathrm{m} \\
\text { Percentage of inorganic fillers - } 46-47 \%\end{array}$ & Ivoclar Vivadent \\
\hline
\end{tabular}

Bis-GMA - Bisphenol- A-Glycidyl dimethacrylate; UDMA - Urethane dimethacrylate, Bis-EMA - Bisphenol A ethoxylate dimethacrylate, TEGDMA - triethylene glycol dimethacrylate; UDMA - Urethane Dimethacrylate; DM-DMA - 1,10-decamethylene dimethacrylate

To obtain the specimens, composite was inserted into the matrix in two increments, and the latter was pressed by a glass slide, preventing the formation of a surface layer with polymerization inhibition by oxygen.

After fabrication, the specimens were stored for 24 hours in a dry ambient in the absence of light. After this, they received surface polishing with wa- ter abrasive papers in a descending order of abrasiveness (granulation of 600,1200 , and 2000). Afterwards, they were separated into 4 groups $(n=6)$, according to the treatment to which they were subjected. In Control Group, the test specimens were immersed in distilled and deionized water at $37^{\circ} \mathrm{C}$ for six 60-minute cycles, totalizing 360 minutes for simulating each period of use. Regarding the fluo- 
ride solutions, $1.23 \%$ acidulated phosphate fluoride (Homeocenter, Ribeirão Preto, SP, Brazil), 2\% neutral fluoride gel (Homeocenter), and $0.05 \%$ fluoride solution for daily mouthrinsing (Homeocenter) were used.

For each product used for professional application (1.23\% phosphate fluoride solution, and $2 \%$ neutral fluoride gel), the test specimens were exposed to two cycles of 4-minute applications, simulating one year of clinical use. After this period, the test specimens were washed and immersed in distilled and deionized water at $37^{\circ} \mathrm{C}$ for 30 minutes to obtain chemical equilibrium at the material surface, and provide an intermediate period between tests. The 8-minute period was stipulated by simulating the condition of clinical use of TAF during a 1-year preventive treatment, in other words, 4-minute applications per session, 2 sessions/year ${ }^{10}$.
Regarding the fluoride solution for daily mouthrinsing $(0.05 \%)$, six 60-minute immersion cycles were performed, and at the end of each cycle the specimens were washed and immersed in distilled and deionized water for 30 minutes at $37{ }^{\circ} \mathrm{C}$ to obtain chemical equilibrium at the material surface ${ }^{10}$, totalizing 360 minutes of immersion, which is a period equivalent to one year of clinical use. All treatments were repeated 5 times, trying to simulate 5 years of clinical use. After each period equivalent to one year of clinical use, color and surface roughness readings were performed.

Color reading was performed using the spectrophotometer PCB 6807 (BYK Gardner, Geretsried, Germany - Fig. 1A), with samples placed against a white standard background (White Standard Sphere for 45\% $/ 0^{\circ}$ Reflectance and Color, Gardner Laboratory Inc., Bethesda, USA - Fig. 1B), according to CIE L*a* $\mathrm{b}^{*}$ system (Comission Internationale de I'Éclairage).
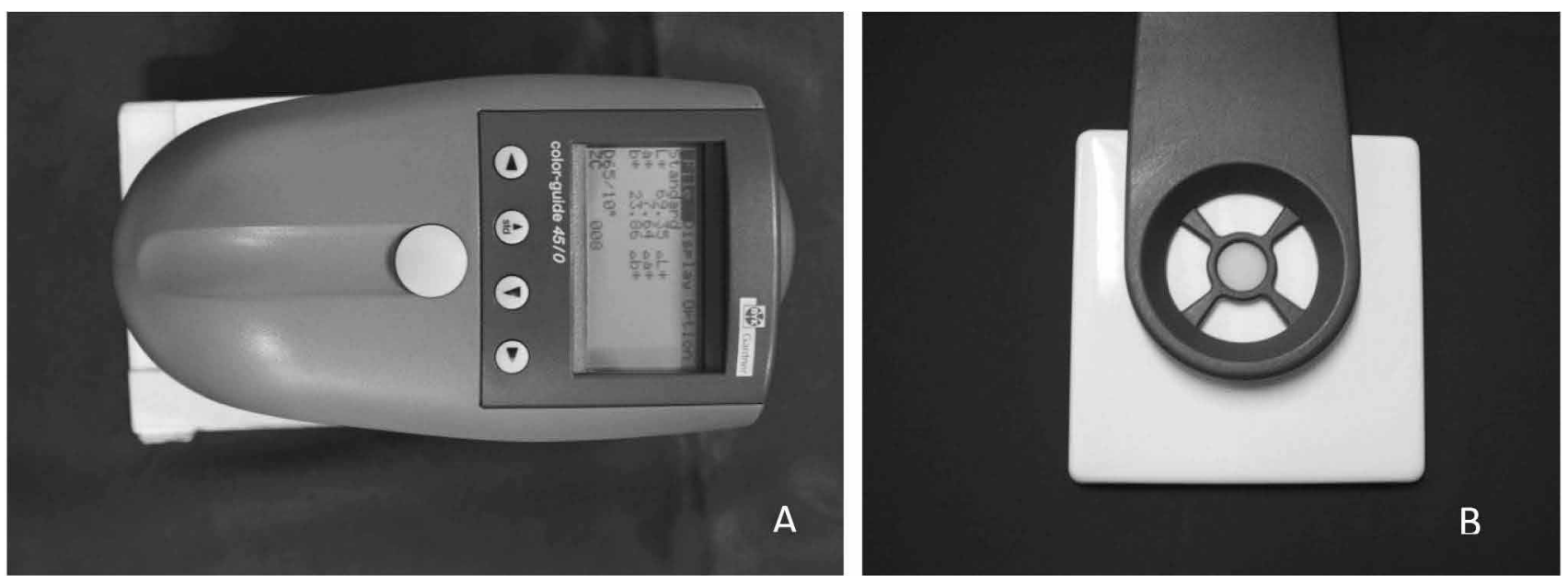

Figure 1 - A) Spectrophotometer PCB 6807 (Byk Gardner). B) Sample placed on a white standard background

Color stability $(\Delta \mathrm{E})$ was determined by using the coordinates $\mathrm{L}^{*}, \mathrm{a}^{*}$, and $\mathrm{b}^{*}$ obtained from the samples before and after immersion, calculated by the formula ${ }^{4}$ :

$\Delta \mathrm{E}^{*}=\left[\left(\Delta \mathrm{L}^{*}\right)^{2}+\left(\Delta \mathrm{a}^{*}\right)^{2}+\left(\Delta \mathrm{b}^{*}\right)^{2}\right]^{1 / 2}$

where: $\Delta \mathrm{L}^{*}=\mathrm{L}_{\mathrm{F}}^{*}-\mathrm{L}_{\mathrm{I}}^{*} ; \Delta \mathrm{a}^{*}=\mathrm{a}_{\mathrm{F}}^{*}-\mathrm{a}_{\mathrm{I}}^{*}$; and $\Delta \mathrm{b}^{*}=\mathrm{b}_{\mathrm{F}}^{*}-\mathrm{b}_{\mathrm{I}}^{*}$

The coordinates $\mathrm{L}^{*}, \mathrm{a}^{*}$, and $\mathrm{b}^{*}$ refer to the initial color measurement and $\mathrm{L}_{\mathrm{F}}^{*}, \mathrm{a}_{\mathrm{F}}^{*}$, and $\mathrm{b}_{\mathrm{F}}^{*}$ refer to the final measurement. The values of $\Delta \mathrm{E} \geq 3.3$ were considered clinically unacceptable ${ }^{11}$.

The surface roughness readings were performed using a roughness meter Surfcorder SE 1700, (Kosakalab, Tokyo, Japan - Fig. 2), and pick-up of 0.8 × $5.0 \mathrm{um}$. Initial surface roughness measurement was performed as soon as the test specimens were fabricated. After each immersion period in the fluoride solutions, new surface roughness readings were performed up to a 5-year simulation period, obtaining the final surface roughness value. For each test specimen, three roughness measurements were performed at each immersion period, and the surface roughness value of the sample was obtained by the arithmetic mean of three readings.

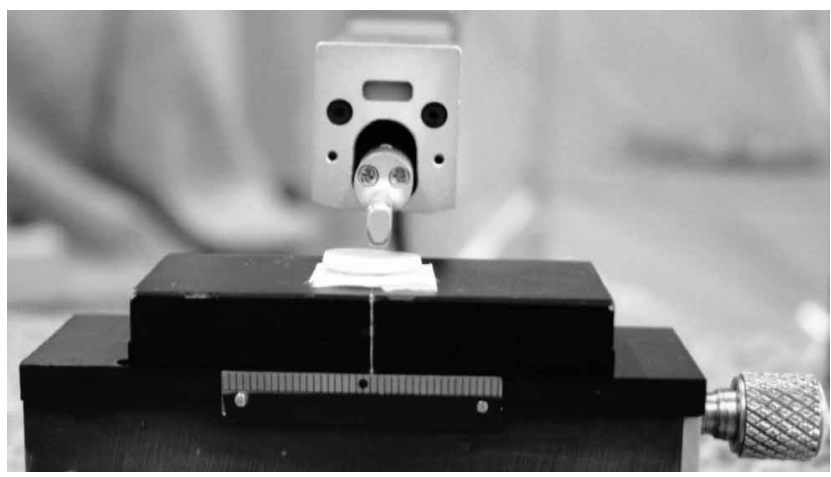

Figure 2 - Sample submitted to surface roughness reading

The results were submitted to the normality test and statistical analysis (3-way repeated measures ANOVA, Bonferroni's test at a significance level of 5\%) (Graphpad Prism 4.0 Software, La Jolla, CA, EUA). 


\section{Results}

\section{Color stability}

All composites presented color change within a clinically acceptable limit $(\Delta \mathrm{E}<3.3)$ (Fig. 3$)$, howe- ver, a tendency for increased color change occurred year after year. When composites were compared, Tetric N-Ceram presented the greatest color change after 3 years of simulation, and SR Adoro presented the lowest color change after 5 years of simulation of clinical use.

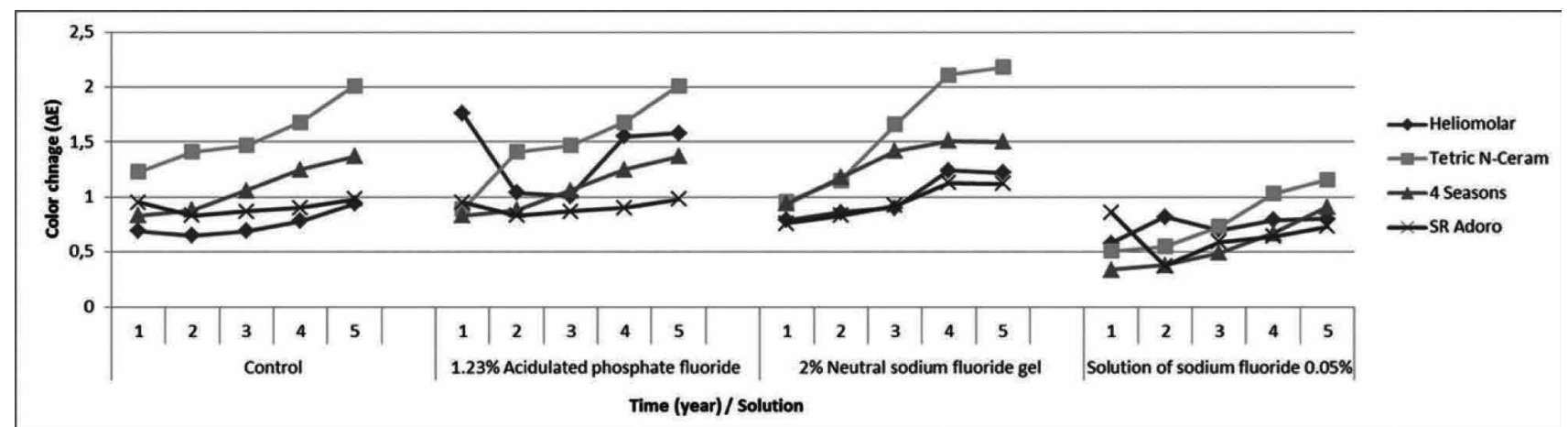

Figure 3 - Color change mean values $(\Delta E)$ of studied composites

\section{Surface roughness}

Composites presented surface roughness change below the critical limit to promote biofilm retention $\left(R_{a}>0.2 \mu \mathrm{m}\right)(\text { Fig. } 4)^{12}$. Furthermore, they did not presented regular behavior over the course of time, preventing to detect which solution caused greater alteration in the materials. Tetric N-Ceram presented the greatest surface roughness change after 5 years of clinical simulation, and SR Adoro the lowest values, except for the Control Group.

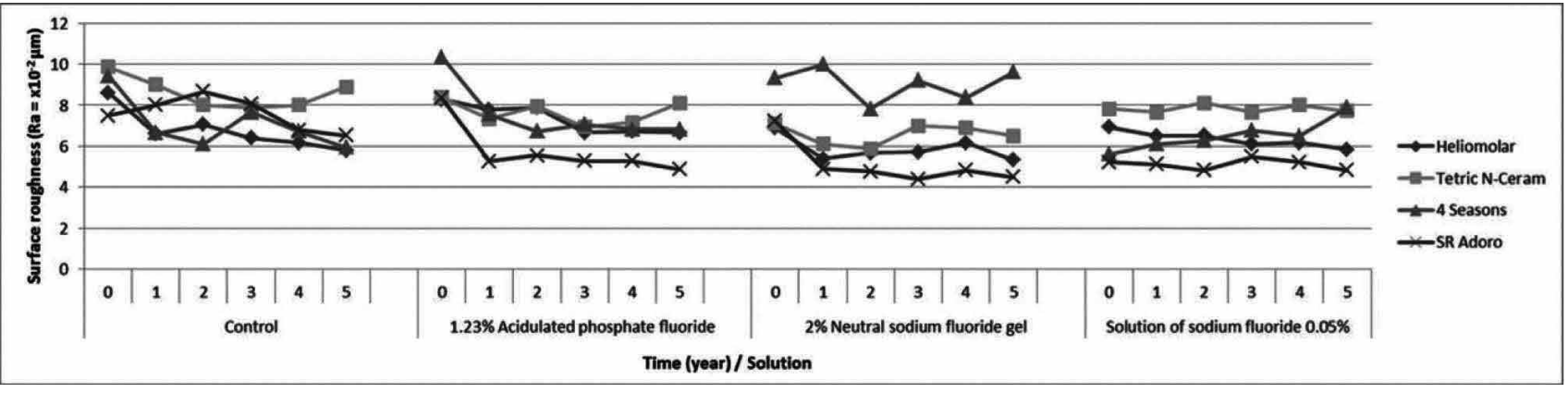

Figure 4 - Surface roughness mean values (Ra) of studied composites

\section{Discussion}

In the present study, the limit of clinical acceptance adopted for esthetic restorative materials was $\Delta \mathrm{E}<3$ 3.3. Therefore, part of the first tested hypothesis was rejected, since there was no significant color alteration after acidulated fluoride solution application in comparison with Control Group.

However, the second tested hypothesis was partially accepted, since a discrete color alteration was observed in the $2 \%$ neutral fluoride gel group, within the clinically acceptable limit ${ }^{11}$, with no significant difference in comparison to fluoride solutions assessed, and Control Group.

Indirect dental composites have improved properties, such as higher color stability ${ }^{13}$, despite being subject to the action of fluoride solutions ${ }^{14}$, as proven by the results of the present study. This class of composites uses a polymerization system complemented by light and heat, which, according to Kildal and Ruyter ${ }^{15}$ (1994), increases its rate of monomer conversion. While Bis-GMA/TEGDMA-based conventional direct composites have a conversion rate of $55 \%^{16}$, indirect composites have a conversion rate ranging from $70 \%$ to $98.5 \%{ }^{17}$.

Furthermore, composite formulation may affect color stability of composites ${ }^{18}$. TEGDMA-based composites absorb more water than UDMA-based composites ${ }^{19}$, which, in turn, absorb less water than the Bis-GMA-based types ${ }^{20}$. However, according to Choi et al. ${ }^{21}$ (2006), the combination of Bis-GMA and TEGDMA monomers provides less color stability to the composite.

Although SR Adoro composite has TEGDMA in its composition, this composite presented the lowest color alteration after 5 years of simulation. 
Such fact could be explained by the complementary polymerization process using the light and heat of this composite, thus resulting in higher conversion degree and less space in the polymeric network, reducing water sorption.

The solvent inside the resin matrix may cause deterioration of the resin matrix/filler interface, a phenomena called plasticization ${ }^{20}$, causing bond relaxation among polymer chains and consequently, color alteration ${ }^{20}$. Also, fluoride solutions cause significant oxidation to the residual carbon-carbon double bonds $(\mathrm{C}=\mathrm{C})$ due to their high reactivity, which leads to the possible formation of formaldehyde, thus causing the plasticization of the polymeric network ${ }^{10}$. Therefore, the longer the time of action of fluoride solution on the composite, the greater its color alteration ${ }^{7}$, which justifies the results of the present study.

Moreover, fluoride ion may cause depolymerization of the resin matrix/filler interface, breaking the chemical bonds inside the composite, allowing water and/or solvent penetration and further degrading of the resin matrix ${ }^{13}$. The greater the action of fluoride ions at the resin matrix/filler interface in the composite, the greater the action on its physical-mechanical properties ${ }^{13}$, which makes the third hypothesis acceptable.

The type and size of the fillers also may affect color stability of composites, since hydrolytic degradation at the filler/resin matrix interface modifies light scattering by filler present in the composite ${ }^{22}$.

The smaller the filler of a composite, the higher its color stability ${ }^{22}$. Hosoya et al. ${ }^{5}$ (2011) observed in their study that acidulated phosphate fluoride gel application did not promote significant color alteration in nanospherical filled composites, which did not agree with the findings of the present study, since the composite with the highest color change was Tetric N-Ceram, a nanohybrid composite.

Fillers dissolution is normally observed in composites, which have barium in their composition, after exposure to acid fluoride solutions ${ }^{13}$. Soeno et al. ${ }^{13}$ (2001) have reported that fluoride ions promote extensive degradation of barium aluminum silicate glass, silicates and zinc glass fillers. This may explain the greater color change of Tetric N-Ceram, which has barium aluminum silicate glass in its composition. Such increase in filler dissolution/debonding is the result of an increase in the exposure area of the resin matrix, and consequently, acceleration of the hydrolytic or hydrolysis effect ${ }^{13}$. The gels used for TAF contain phosphoric acid and hydrofluoric acid, which may cause loss of fillers ${ }^{10}$.

Acidulated phosphate fluoride etches enamel, allowing better penetration of fluoride ${ }^{10}$. However, hydrogen ions from phosphoric acid and fluoride ions from sodium fluoride are also present in the composition of this gel, which may react and form hydrofluoric acid ${ }^{13}$, and dissolve the surface of restorative materials that have inorganic components in their composition, such as ceramics ${ }^{10}$, glass ionomers ${ }^{6}$, and particularly composite, creating gaps and increasing surface roughness ${ }^{5}$.

The results of the present study did not presented surface roughness alterations perceptible by the patient $\left(R_{a}>0.3 \mu \mathrm{m}\right)$ or even minimum roughness needed for biofilm retention $\left(R_{a}>0.2 \mu \mathrm{m}\right)^{12}$, contrary to the findings of other studies ${ }^{10,6}$. This allows us to reiterate the rejection of the first hypothesis and partially reject the second hypothesis, because in spite of the $2 \%$ neutral fluoride gel not being able to alter surface roughness above the critical level, there was some alteration, however, within clinically acceptable limits.

Microfiller and microhybrid composites are less subject to degradation after $\mathrm{TAF}^{2}$. As type and size of fillers in composites are different, behaviors regarding the action of fluoride solutions are heterogeneous ${ }^{2}$. The same occurred in the present study, in which fluoride solutions did not interfere in surface roughness after 1 and 2 years of simulation, regardless of the composite fillers content. After this initial simulation period, a greater difference among composites was observed at the same period and for the same fluoride solution.

\section{Conclusions}

Further studies are needed to better assess the action of fluoride solutions on dental composites, because, clinically, the effect of these solutions may be modified by the presence of saliva as a diluent and buffering agent. However, in spite of the limitations of the study, it may be concluded that color and roughness alteration of composites were clinically acceptable and material dependent.

\section{Resumo}

Objetivo: O objetivo deste estudo foi avaliar a ação de soluções fluoretadas sobre a estabilidade de cor $(\Delta E)$ e rugosidade de superfície $\left(R_{a}\right)$ de compósitos (Heliomolar $^{\circledR}, 4$ Seasons $^{\circledR}$, Tetric N-Ceram ${ }^{\circledR}, S R$ Adoro $\left.{ }^{\circledR}\right)$. Materiais e método: Uma matriz de Teflon $(12 \times 2 \mathrm{~mm})$ foi utilizada para confeccionar 24 corpos-de-prova de cada compósito. As amostras foram separadas em 4 grupos $(n=6)$, de acordo com a solução na qual foram imersas: água destilada (controle), fluoreto de fosfato acidulado $(1,23 \%)$, fluoreto de sódio neutro (2\%) e solução de sódio fluoretada $(0,05 \%)$. Leituras de cor (Espectrofotômetro PCB 6807) e rugosidade (Surfcorder SE 1700) foram realizadas antes e após a imersão nas soluções. Resultados: Os compósitos apresentaram alteração de cor dentro dos limites clinicamente aceitáveis $(\Delta E<3,3)$, que foi aumentando de acordo com os períodos de imersão. Em relação à rugosidade, observou-se que os valores de $R_{a}$ foram inferiores ao limite crítico para pro- 
mover aumento na retenção de biofilme $\left(R_{\mathrm{a}}>0,2 \mathrm{~mm}\right)$. Conclusões: Os diferentes compósitos apresentaram alteração de cor e rugosidade de superfície clinicamente aceitáveis após imersão em todas as soluções fluoretadas e em todos os períodos.

Palavras-chave: Compósitos. Cor. Propriedades de superfície. Fluoreto de fosfato acidulado.

\section{References}

1. Yap AU, Yap SH, Teo CK, Nq JJ. Comparison of surface finish of new aesthetic restorative materials. Oper Dent 2004; 29(1):100-4.

2. Soeno K, Matsumura H, Kawasaki K, Atsuta M. Influence of acidulated phosphate fluoride agents on surface characteristics of composite restorative materials. Am J Dent 2000; 13(6):297-300.

3. Jones CS, Billington RW, Pearson GJ. The in vivo perception of roughness of restoration. Br Dent J 2004; 196(1):42-5.

4. Mundim FM, Da Fonseca Roberti Garcia L, Silva Sousa AB, Cruvinel DR, De Carvalho Panzeri Pires-De-Souza F. Influence of artificial accelerated aging on the color stability and opacity of composites of different shades. Minerva Stomatol 2010; 59(10):535-41.

5. Hosoya Y, Shiraishi T, Puppin-Rontani RM, Powers JM. Effects of phosphate fluoride gel application on surface roughness, gloss and colour of different type resin composites. J Dent 2011; 39(10):700-6.

6. El-Badrawy WA, McComb D, Wood RE. Effect of home-use fluoride gels on glass ionomer and composite restorations. Dent Mater 1993; 9(1):63-7.

7. Yeh ST, Wang HT, Liao HY, Su SL, Chang CC, Kao HC, et al. The roughness, microhardness, and surface analysis of nanocomposites after application of topical fluoride gels. Dent Mater 2011; 27(2):187-96

8. Shabzendedar M, Moosavi H, Kebriaee F, Daneshvar-Mozafari A. The effect of topical fluoride therapy on microleakage of tooth colored restorations. J Conserv Dent 2011; 14(3):297301.

9. Butler CJ, Masri R, Driscoll CF, Thompson GA, Runyan DA, Anthony von Fraunhofer J. Effect of fluoride and 10\% carbamide peroxide on the surface roughness of low-fusing and ultra low-fusing porcelain. J Prosthet Dent 2004; 92(2):179-83.

10. Papagiannoulis L, Tzoutzas J, Eliades G. Effect of topical fluoride agents on the morphologic characteristics and composition of resin composite restorative materials. J Prosthet Dent 1997; 77(4):405-13.

11. Ruyter IE, Nilner K, Möller B. Color stability of dental composite resin materials for crown and bridge veneers. Dent Mater 1987; 3(5):246-51.

12. Bollen C, Lambrechts P, Quirynen M. Comparison of surface roughness of oral hard materials to the threshold surface roughness for bacterial plaque retention: a review of the literature. Dent Mater 1997; 13(4):258-69.

13. Soeno K, Matsumura H, Atsuda M, Kawasaki K. Effect of acidulated phosphate fluoride solution on veneering particulate filler composite. Int J Prosthodont 2001; 14(2):127-32.
14. Tanoue N, Soeno K, Kawasaki K, Atsuta M. Influence of acidulated phosphate fluoride solution on the color stability of indirect composites. J Prosthet Dent 2004; 92(4):343-7.

15. Kildal KK, Ruyter IE. How different curing methods affect the degree of conversion of resin-based inlay/onlay materials. Acta Odontol Scand 1994; 52(5):315-22.

16. Soares LES, Liporoni PCS, Martin AA. The effect of softstart polymerization by second generation LEDs on the degree of conversion of resin composite. Oper Dent 2007; 32(2):160-5.

17. Miara P. Aesthetic guidelines for second-generation indirect inlay and onlay composite restorations. Pract Periodontics Aesthet Dent 1998; 10(4):423-31.

18. Papadopoulos T, Sarafianou A, Hatzikyriakos A. Colour stability of veneering composites after accelerated aging. Eur J Dent 2010; 4(2):137-42.

19. Santerre JP, Shajii L, Leung BW. Relation of dental composite formulations to their degradation and the release of hydrolyzed polymeric-resin-derived products. Crit Rev Oral Biol Med 2001; 12(2):136-51.

20. Ferracane JL. Hygroscopic and hydrolytic effects in dental polymer networks. Dent Mater 2006; 22(3):211-22.

21. Choi MS, Lee YK, Lim BS, Rhee SH, Yang, HC, Lim YJ. Changes in color and translucency of porcelain-repairing resin composites after thermocycling. J Biomed Mater Res Part B: Appl Biomater 2006; 78(1):1-6.

22. Lee YK, Lim BS, Rhee SH, Yang HC, Powers JM. Color and translucency of A2 shade resin composites after curing, polishing and thermocycling. Oper Dent 2005; 30(4):436-42.

\section{Corresponding author:}

Fernanda de Carvalho Panzeri Pires-de-Souza Address: Faculdade de Odontologia de Ribeirão Preto - USP, Departamento de Materiais Dentários e Prótese, Avenida do Café, s/n, Bairro Monte Alegre 14040-904 Ribeirão Preto / SP - Brazil Telephone: +55 (016) 3602-3973

Fax: +55 (016) 3633-0999

E-mail: ferpanzeri@usp.br

Recebido: 22 /11/2013. Aceito: 16/01/2014. 